\title{
Assessment of the role of EGF +61A/G and EGFR R497K polymorphism in patients with inflammatory bowel disease: A case-control study
}

\author{
Inflamatuar bağırsak hastalığında EGF $+61 \mathrm{~A} / \mathrm{G}$ ve EGFR R497K polimorfizm rolünün \\ değerlendirilmesi: Bir olgu-kontrol çalışması
}

\author{
Resul Kahraman ${ }^{1}$, Elif Sinem İplik ${ }^{2}$, Turan Çalhan ${ }^{1}$, Abdurrahman Şahin ${ }^{1}$, Bedia Çakmakoğlu ${ }^{3}$
}

\begin{abstract}
Aim: Epidermal growth factor (EGF) and epidermal growth factor receptor (EGFR) play an important role in the regulation of cell growth, survival, migration, apoptosis, proliferation, and differentiation. We aimed to investigate the presence of EGF $(+61 \mathrm{~A} / \mathrm{G})$ and EGFR R497Kpolymorphisms in patients with inflammatory bowel disease (IBD) and their associations with clinical features of the patients.

Methods: This case-control study included 91 IBD patients (45 Crohn's disease (CD) patients and 46 ulcerative colitis (UC) patients) and 129 healthy controls (HC).EGF and EGFR were genotyped by polymerase chain reaction and restriction fragment length polymorphism techniques to elucidate their association with clinica outcomes. The disease activity for UC and CD were assessed by Truelove-Witts index (TW) and Crohn's disease activity index (CDAI), respectively. The Montreal classification was used for disease involvement and behavior.

Results: EGFR497 AA genotype was significantly decreased in patients with UC compared with CD and HC. In addition, the patients with UC who had EGF $+61 \mathrm{~A}$ allele had increased risk of moderate and severe disease $(\mathrm{p}=0.28 ; \mathrm{OR}=3.13 ; 95 \% \mathrm{CI}=0.34-28.73)$. The patients with $\mathrm{CD}$ who had the EGF61 AG genotype were found to increased risk for the presence of penetrating disease ( $\mathrm{p}=0.14 ; \chi 2=5.59 ; \mathrm{OR}=5.00 ; 95 \% \mathrm{CI}=1.26-19.83)$. EGF +61 A genotype carriers also had higher CDAI scores $(\mathrm{p}=0.19$; $\mathrm{OR}=4.00 ; 95 \% \mathrm{CI}=0.44-36.14)$. In addition, $\mathrm{A}+$ carriers were also found to have higher requirement for anti-TNF treatment $(\mathrm{p}=0.11 ; \mathrm{OR}=5.0 ; 95 \% \mathrm{CI}=0.56$ 44.4).

Conclusion: In this study, EGFR 497 AA genotype was found to decrease significantly in patients with UC compared to $\mathrm{HC}$ and $\mathrm{CD}$ patients. To enlighten the mechanism, further studies with larger sample groups are needed to clarify the role of the EGF (+61 A/G) and EGFR R497K genes polymorphism, and development of the etiology and pathogenesis of IBD.

Keywords: EGF61, EGFR497, inflammatory bowel diseases, Crohn's disease, ulcerative colitis
\end{abstract}

Öz

Amaç: Epidermal büyüme faktörü (EGF) ve epidermal büyüme faktörü reseptörü (EGFR), hücre büyümesi, canlılı̆ı̆, migrasyonu, apoptoz, proliferasyon ve farklılaşmasının düzenlenmesinde önemli bir rol oynamaktadır İnflamatuar barsak hastalığı (iBH) olan hastalarda EGF (+61A/G) ve EGFR R497K polimorfizmlerinin varlığın ve hastalığın klinik özellikler ile ilişkisini araştırmayı amaçladık.

Yöntemler: Bu vaka kontrol çalışmasında 91 IBD hastası (45 Crohn hastalığı (CD) hastası ve 46 ülseratif kolit (UC) hastası) ve 129 sağlıklı kontrol (HC) vardı. EGF ve EGFR, polimeraz zincir reaksiyonu ve restriksiyon fragman uzunluğu polimorfizm teknikleri ile hastalık ve sağlıklı control grubu genotiplendirildi. Genotiplerinhastalık ve klinik özellikleri ile ilişkileri incelendi. UC ve CD için hastalık aktivitesi sırasıyla Truelove-Witts indeksi (TW) ve Crohn hastalığı aktivite indeksi (CDAI) ile değerlendirildi. Montreal sınıflandırması hastalık tutulumu ve davranışı için kullanılmıştır.

Bulgular: Ulseratif kolit hastalarında EGFR497 AA genotipi CD ve HC'ye göre anlamlı olarak azaldığ saptanmıştır. Ek olarak, EGF +61 A alleli olan UC'li hastalarda orta ve ciddi hastalık riski artmıştır $(\mathrm{p}=0.28$; $\mathrm{OR}=3.13 ; \% 95 \mathrm{CI}=0.34-28.73) . \mathrm{EGF}+61 \mathrm{AG}$ genotipine sahip olan $\mathrm{CD}^{\prime}$ li hastalarda penetran hastalık varlığ 1 açısından artmış risk bulundu $\left(\mathrm{p}=0.14 ; \chi^{2}=5.59 ; \mathrm{OR}=5.00 ; \% 95 \mathrm{CI}=1.26-19.83\right)$. EGF $+61 \mathrm{~A}$ alleli taşıyıcılarında daha yüksek CDAI skor riski saptandı $(\mathrm{p}=0.19$; $\mathrm{OR}=4.00 ; \% 95 \mathrm{CI}=0.44-36.14)$. Ek olarak, $\mathrm{CD}$ hastalarında EGF $+61 \mathrm{~A}$ alleli taşıyıcılarının anti-TNF tedavi gereksinimi için artmış riske sahip olduğu bulunmuştur $(\mathrm{p}=0.11 ; \mathrm{OR}=5.0 ; \% 95 \mathrm{CI}=0.56-44.4)$.

Sonuç: Bu çalışmada, UC'li hastalarda EGFR497 AA genotipinde HC ve CD'li hastalara kıyasla, anlamlı azalma saptandı. EGF $+61 \mathrm{~A}$ allele sahip hastalarda artmış aktivite riski saptanmıştır.IBD'nin etiyolojisi ve patogenezinde EGF (+ 61A / G) ve EGFR R497K gen polimorfizminin rolünü açıklığa kavuşturmak için daha geniş örnek gruplarıyla daha fazla çalışmaya ihtiyaç vardır.

Anahtar Kelimeler: EGF +61A/G, EGFR R497K, inflammatuar bağırsak hastalı̆̆ı, Crohn's hastalığı, ülseratif kolit
${ }^{1}$ Department of Gastroenterology, University of Health Sciences, Ümraniye Education and Resarch Hospital, Istanbul, Turkey.

${ }^{2}$ Department of Pharmaceutical Microbiology, Faculty of Pharmacy, Istanbul Yeni Yuzyll University, Istanbul, Turkey.

${ }^{3}$ Department of Molecular Medicine, Institute for Experimental Medicine Research, Istanbul University, Istanbul, Turkey.

Ethics Committee Approval: The study wass approved by the local ethical authority.

Etik Kurul Onayı: Çalışma lokal etik komite tarafindan onaylanmıştır.

Conflict of Interest: No conflict of interest was declared by the authors.

Çıkar Çatışması: Yazarlar çıkar çatışması bildirmemișlerdir.

Financial Disclosure: The authors declared that this study has received no financial support.

Finansal Destek: Yazarlar bu çalıșma için finansal destek almadıklarını beyan etmişlerdir.

Geliş Tarihi / Received: 18.04.2018

Kabul Tarihi / Accepted: 11.06.2018

Yayın Tarihi / Published: 20.07.2018

Sorumlu yazar / Corresponding author:

Bedia Çakmakoğlu

Istanbul University, Institute of Experimental Medical, Department of Molecular Medicine,

Capa, Istanbul, Turkey

Phone: +90 $2124142000-33305$

Fax: +90 212532417

E-mail: bedia@istanbul.edu.tr

Copyright $($ ) ACEM 


\section{Introduction}

The inflammatory bowel diseases (IBD) are chronic relapsing inflammatory disorders of the alimentary tract with unknown etiology. Interactions between genetic and environmental factors and exaggerated immunologic response against several antigens have been accepted as included in the etiopathogenesis of IBD [1]. IBD mainly consists of two diseases according to clinical and histopathologic features: Crohn's disease (CD) and ulcerative colitis (UC).

The intestinal epithelial layer is a barrier that prevents the transport of several toxins, allergens, and microorganisms from the gut lumen into the circulation. Dysfunction of this barrier is associated with increased gut permeability, which is claimed as one of the factors in the etiopathogenesis of IBD. Several growth factors maintain gut mucosal integrity, including transforming growth factor $\beta$ (TGF- $\beta$ ), insulin-like growth factor (IGF), and epidermal growth factor (EGF) [2].

Epidermal growth factor (EGF) is a mitogenic polypeptide that has 53 amino acids except for alanine, phenylalanine, and lysine [3]. EGF has been detected in a variety of body fluids and plays an important role in regulating cell growth, survival, migration, apoptosis, proliferation, and differentiation [4]. Another important function of EGF in the gastrointestinal tract (GI) is mucosal protection associated with intestinal maturation and maintenance of epithelial cell homeostasis in the small intestine [4]. Experimental studies have shown that EGF plays an important role in protecting the intestinal barrier function, and wound healing in necrotizing enterocolitis and ischemia-reperfusion injury models $[5,6]$. It has been shown that EGF has anti-inflammatory effects in human fetal intestinal and colonic cells [7]. It has been determined that a single nucleotide polymorphism located in the 5 ' untranslated region at position 61 of the EGF gene affects expression levels of EGF [8, 9]. Shahbazi et al. [10] demonstrated that cells of individuals with the EGF 61 AA genotype produce less EGF compared with those with EGF 61 AG and GG genotypes. In addition, $\mathrm{Wu} \mathrm{G}$, et al. [11] noted an important role between EGF +61 GG genotype and the $+61 \mathrm{G}$ allele with the risk of colorectal cancer. Inflammation has been shown to induce genetic or epigenetic changes in cells, resulting in overexpression or persistent activation of endothelial growth factor receptors, thereby activating oncogenesis-related pathways [11].

EGF receptor (EGFR) is a $170-\mathrm{kDa}$ transmembrane glycoprotein encoded by a gene located on chromosome 7p13q22. EGFR serves as the common receptor for EGF and transforming growth factor- $\alpha(\mathrm{TGF}-\alpha)[5,12]$. EGFR is a tyrosine kinase that manages cell survival, proliferation, barrier function, and ion transport of colon epithelial homeostasis [13]. The receptors could be found on a variety of cells such as fibroblasts, cornea, lens, glial cells, and epithelium of the small intestine [14, $15]$.

One of the major receptors of polymorphic EGFR has been identified; it plays its role as a single nucleotide change (GA) belonging to an arginine to lysine substitution in codon 497, which is also called R497K, in the extracellular domain [16]. The EGFR R497K polymorphism has been shown to reduce EGFR activation and downregulate EGFR target genes. This has been demonstrated to be an important marker for the reduction of tumor recurrence in patients with colorectal carcinoma [17]. Animal models and cell culture studies revealed the antiinflammatory role of EGF an EGFR in intestinal inflammation models [7, 18].

In the present study, we aimed to investigate the presence of EGF +61A/G and EGFR 497 polymorphisms in patients with IBD and the association of these polymorphisms with the clinical features of the patients with $\mathrm{CD}$ and $\mathrm{UC}$ compared with healthy subjects.

\section{Material and Methods}

\section{Subjects}

In total, 220 Turkish subjects, 91 patients with IBD (45 CD and 46 UC) and 129 healthy control subjects were enrolled consecutively in the study. The characteristics of the patients with CD (Group 1) and UC (Group 2) and control group (Group 3 ) and demographic data are given in Table 1. This study was designed as a case-control study. The patient group was selected from patients diagnosed with UC and CD according to European Crohn's and Colitis Organization (ECCO-2010) criteria and followed up at the Gastroenterology Clinic of the Umraniye Education and Research Hospital (Istanbul-Turkey) between January 2012 and December 2013 [19]. The control group included age- and sex-matched volunteers from hospital staff and volunteers from among individuals who admitted to the Gastroenterology Clinic for dyspeptic complaints. Subjects in the control group were individuals not having an inflammatory disease or systemic disorder. After obtaining written informed consent from the participants and approval from Istanbul University's Ethics Committee, blood specimens were collected in tubes containing EDTA. DNA was ex $\neg$ tracted from peripheral blood lymphocytes using the salting-out procedure. Disease activity and severity were evaluated using the Truelove-Witts index (TW) in patients with UC and with the Crohn's Disease Activity Index (CDAI) in patients with CD [20]. Patients with $\mathrm{CD}$ were divided into three groups as mild (CDAI= 150-220), moderate $(\mathrm{CDAI}=220-450)$, and severe activity $(\mathrm{CDAI}>450)$. The location and behavior of disease are classified according to the Montreal classification. [21]. The CD location is classified as L1 terminal ileum with or without cecum involvement (L1), colon (L2), ileocolon (L3). According to the CD behavior, three groups were separated as nonstricturing, nonpenetrating (B1), stricturing (B2) and penetrating (B3). Patients with UC were divided into three groups according to the extent of disease: distal (proctosigmoiditis) colitis was determined as inflammation limited to the rectum and sigmoid colon; left-sided colitis, determined as inflammation limited to distal of the splenic flexure; and extensive colitis, involvement exceeding the splenic flexure. Patients were also divided into two groups according to whether they had surgery or not. The patients were also divided into mesalazine, azathioprine and anti-tumor necrosis factor alpha drugs (infliximab and adalimumab) according to their treatment.

\section{Polymorphism analysis and RFLP for EGFR R497K and EGF +61A/G}

Genomic DNA was extracted from isolated lymphocytes using a standard nonorganic procedure. The 
extracted DNA was used for characterization of the subsequent polymorphic genes. Polymerase chain reaction (PCR), followed by restriction fragment length polymorphism (RFLP), was used for genotyping. Initially, PCR was performed to determine the polymorphic regions using suitable primers. PCR products of EGFR R497K and EGF +61A/G were further subjected to digestion using BstN1 and AluI restriction enzymes, respectively (Table 2). The PCR products were visualized using electrophoresis through a $3 \%$ agarose gel. The relative size of the PCR products was determined by comparison of the migration of a 50-1000 bp DNA molecular weight ladder. A permanent visual image was obtained using an ultraviolet (UV) illuminator. Two independent researchers read all genotypes. In the event of any conflicts, the genotypes were repeated.

\section{Statistical analysis}

SPSS 11.0 software was used for statistical analysis. The Chi-square test and Fisher's test were used to assess the differences of genotype and allele frequency between the two groups. Comparison of intergroup demographic data was determined using Student's t-test. ANOVA and t-test were used to compare averages of variables in more than two groups. The calculation of differences between sexes was made using the Chi-square test. For the assessment of correlation between the variables, Pearson's and Spearman's correlation analyses were conducted for parametric and nonparametric variables, respectively. Quantitative variables were expressed as mean \pm SD (standard deviation) and median (Minimum / Maximum), and categorical variables were expressed as $\mathrm{n}(\%)$. Variables were examined at $95 \%$ confidence interval. A p value of $<0.05$ was considered statistically significant.

\section{Results}

The demographic and laboratory data of patients with $\mathrm{CD}, \mathrm{UC}$, and the control group are presented in Table 1. There were no significant differences between the three groups in terms of age and sex. Patients with UC and CD did not differ in terms of the disease duration. Table 3 summarizes the distributions of genotypes and alleles of EGF +61A/G and EGFR R497K genes in patients with IBD including $\mathrm{CD}$ and $\mathrm{UC}$ and healthy controls.

The EGFR497 AA genotype was significantly decreased in patients with UC compared with $\mathrm{HC}$ ( $\mathrm{p}=0.002$ and $\mathrm{CD}(\mathrm{p}=0.027)$. Nevertheless, there was no statistically significant difference in EGF +61 genotype frequencies between the three groups (all $\mathrm{p}>0.05$ ). EGF $+61 \mathrm{~A} / \mathrm{G}$ and EGFR497 polymorphisms were compared in terms of disease localization, severity, antiTNF drug use, and operative status in both disease groups (Table $4,5)$. The patients with CD who had EGF +61 AG genotype were found to have a 5 -fold increased risk for the presence of penetrating disease $(\mathrm{p}=0.14 ; \chi 2=5.59 ; \mathrm{OR}=5.00 ; 95 \% \mathrm{CI}=1.26$ 19.83). EGF +61 A allele carriers also had higher CD activity index (CDAI >220) scores ( $\mathrm{p}=0.19$; $\mathrm{OR}=4.00$; 95\% $\mathrm{CI}=0.44$ 36.14). In addition, $A+$ carriers were also found to have five times higher requirement for anti-TNF treatment $(\mathrm{p}=0.11$; $\mathrm{OR}=5.0 ; 95 \% \mathrm{CI}=0.56-44.4$ ). Based on the extension of $\mathrm{CD}$, EGF +61 AG genotype carriers had a 2.5-fold higher risk of ileocolonic involvement $(\mathrm{p}=0.14$; $\mathrm{OR}=2.56$; 95\% CI=0.66-9.96). The patients with UC who had the $\mathrm{EGF}+61$ A allele had increased risk of moderate and severe disease $(\mathrm{p}=0.28$; $\mathrm{OR}=$ $3.13 ; 95 \% \mathrm{CI}=0.34-28.73)$.

Table 1: Characteristics of patients with CD and UC and control.

\begin{tabular}{|c|c|c|c|c|c|c|}
\hline & Group1 & Group 2 & Group 3 & P1 & P2 & P3 \\
\hline Number (n) & 45 & 46 & 129 & & & \\
\hline Age (year) ${ }^{\beta}$ & $39.4 \pm 11.6$ & $42.0 \pm 11.8$ & $42.8 \pm 14.8$ & 0.182 & 0.085 & 0.560 \\
\hline Sex & & & & & & \\
\hline (Female/Male) & $23 / 22$ & $26 / 20$ & $79 / 50$ & 0.540 & 0.060 & 0.190 \\
\hline $\begin{array}{l}\text { Disease } \\
\text { duration } \\
\text { (month) }^{\beta}\end{array}$ & $38.2 \pm 47.0$ & $56.1 \pm 50.0$ & & 0.085 & & \\
\hline BMI $\left(\mathrm{kg} / \mathrm{m}^{2}\right)^{\beta}$ & $24.4 \pm 6.4$ & $25.3 \pm 5.6$ & $26.3 \pm 3.8$ & 0.264 & 0.084 & 0.498 \\
\hline $\operatorname{CRP}(\mathrm{mg} / \mathrm{dl})^{\beta}$ & $1.57 \pm 3.56$ & $0.74 \pm 1.0$ & $0.47 \pm 0.3$ & 0.084 & 0.046 & 0.140 \\
\hline CD Behavior & & & NA & & & \\
\hline $\begin{array}{l}\text { Nonstr- } \\
\text { nonpenet. }\end{array}$ & 22 & NA & & & & \\
\hline Stricturing & 11 & NA & & & & \\
\hline Penetrating & 12 & NA & & & & \\
\hline CD Location & & & NA & & & \\
\hline Ileal & 20 & NA & & & & \\
\hline Ileocolon & 18 & NA & & & & \\
\hline Colon & 7 & NA & & & & \\
\hline Disease & & & & & & \\
\hline Activity & $23 / 14 / 8$ & $22 / 21 / 3$ & NA & & & \\
\hline Mild/Moderate & & & & & & \\
\hline /Severe & & & & & & \\
\hline UC Location & & & NA & & & \\
\hline Proctitis & NA & 14 & & & & \\
\hline Left-sided & NA & 11 & & & & \\
\hline Extensive & NA & 21 & & & & \\
\hline Treatment & & & NA & & & \\
\hline Mesalazine $^{\alpha}$ & $38(77)$ & $56(100)$ & $1 \mathrm{~N}$ & & & \\
\hline Azathioprine $^{\alpha}$ & $39(80)$ & $18(32)$ & & & & \\
\hline Anti-TNF ${ }^{\alpha}$ & $13(20)$ & 0 & & & & \\
\hline
\end{tabular}

${ }^{\beta}:$ Mean \pm standard deviation, ${ }^{\alpha}: \mathrm{n}(\%)$

Group1: Crohn's disease group, Group 2: ulcerative colitis group, Group 3: healthy control, CD: Crohn's disease, CRP: C-reactive protein, BMI: body mass index, $\mathrm{p} 1$ : $\mathrm{p}$ value between group 1 and group 2, p2: $\mathrm{p}$ value between group 1 and group 3,p3: p value between group 2 and group 3 .

$\begin{aligned} & \text { Table 2: Polymerase chain reaction and restriction fragment length polymorphism methods } \\
& \text { Gene Variants }\end{aligned}$
\begin{tabular}{lll} 
Primers & Enzymes \\
\hline EGFR R497K & 5'-TGCTGTGACCCACTCTGTCT- & BstN1 \\
& 3'5'CCAGAAGGTTGCACTTGTCC-3' & \\
EGF +61 & 5'-TGTCACTAAAGGAAAGGAGGT-3', 5'- & AluI \\
\hline & TTCACAGAGTTTAACAGCCC-3' &
\end{tabular}

Table 3: Distributions of genotypes and alleles of EGF61 and EGFR497

\begin{tabular}{|c|c|c|c|c|c|c|c|c|c|}
\hline \multirow{2}{*}{$\begin{array}{l}\text { Polymor } \\
\text { phism }\end{array}$} & \multicolumn{2}{|c|}{$\underset{n=45}{\text { Group } 1}$} & \multicolumn{2}{|c|}{$\begin{array}{c}\text { Group } 2 \\
n=46\end{array}$} & \multicolumn{2}{|c|}{$\begin{array}{c}\text { Group 3 } \\
n=129\end{array}$} & \multirow[t]{2}{*}{$\mathrm{p}_{1}$} & \multirow[t]{2}{*}{$\mathrm{p}_{2}$} & \multirow[t]{2}{*}{$\mathrm{p}_{3}$} \\
\hline & $\mathrm{n}$ & $\%$ & $\mathrm{n}$ & $\%$ & $\mathrm{n}$ & $\%$ & & & \\
\hline \multicolumn{10}{|c|}{$\mathrm{EGF}(+61 \mathrm{~A} / \mathrm{G})$} \\
\hline$\overline{\mathrm{GG}}$ & 11 & 24.4 & 13 & 28.3 & 28 & 21.7 & 0.704 & 0.367 & 0.680 \\
\hline AA & 17 & 37.8 & 14 & 30.4 & 34 & 26.4 & 0.147 & 0.595 & 0.460 \\
\hline GA & 17 & 37.8 & 19 & 41.3 & 67 & 51.9 & 0.102 & 0.215 & 0.731 \\
\hline $\begin{array}{l}\mathrm{GG}+\mathrm{AG} \\
\text { vs } \mathrm{AA}\end{array}$ & 28 & 62.2 & 32 & 69.6 & 95 & 73.6 & 0.147 & 0.595 & 0.460 \\
\hline $\begin{array}{l}\mathrm{AA}+\mathrm{AG} \\
\text { vs } \mathrm{GG}\end{array}$ & 34 & 75.6 & 33 & 71.7 & 101 & 78.3 & 0.704 & 0.367 & 0.680 \\
\hline \multicolumn{10}{|c|}{ EGFR R497K } \\
\hline$\overline{\mathrm{AA}}$ & 7 & 15.6 & 1 & 2.2 & 25 & 19.4 & 0.569 & 0.002 & 0.027 \\
\hline GG & 20 & 44.4 & 20 & 43.5 & 57 & 44.2 & 0.976 & 0.934 & 0.926 \\
\hline AG & 18 & 40.0 & 25 & 54.3 & 47 & 36.4 & 0.670 & 0.034 & 0.170 \\
\hline $\begin{array}{l}\mathrm{AA}+\mathrm{AG} \\
\text { vs } \mathrm{GG}\end{array}$ & 25 & 55.6 & 26 & 56.5 & 72 & 55.8 & 0.976 & 0.934 & 0.926 \\
\hline GG+AG & 38 & 84.4 & 45 & 97.8 & 104 & 80.6 & 0.569 & 0.002 & 0.027 \\
\hline
\end{tabular}

vs AA

Group1: Crohn's disease group, Group 2: ulcerative colitis group, Group 3: healthy control group, EGF: epidermal growth factor, EGFR: epidermal growth factor receptor, $\mathrm{p} 1$ : p-value between healthy control group and $\mathrm{CD}$ group, p2: $\mathrm{p}$-value between healthy control group and UC group, $\mathrm{p} 3$ : $\mathrm{p}$-value between $\mathrm{CD}$ group and UC group

\section{Discussion}

EGF exerts effects on cell proliferation and differentiation by binding to a tyrosine kinase receptor EGFR. It is well known that EGF and its receptor have roles on the immune system, cell proliferation, and apoptosis. The interaction of EGF and its receptor activates intracellular signaling pathways and has a mitogenic effect. The disruption of this regulation causes various cancers including colon cancer. 
Table 4: Evaluation of EGF +61 A/G and EGFR 497 polymorphisms in patients with CD in relation to disease type, localization, activity, treatment and operative status.

\begin{tabular}{|c|c|c|c|c|c|c|c|}
\hline \multirow{2}{*}{$\mathrm{CD}$} & \multicolumn{2}{|l|}{ EGF61 } & \multicolumn{2}{|c|}{$\begin{array}{l}\text { GG } \\
\mathrm{N} \%\end{array}$} & \multicolumn{2}{|c|}{$\begin{array}{c}\mathrm{GA}+\mathrm{AA} \\
\mathrm{N} \%\end{array}$} & \multirow{2}{*}{$\begin{array}{c}\mathrm{p} \\
0.172\end{array}$} \\
\hline & Localization & Ileal & 7 & 35.0 & 13 & 65.0 & \\
\hline & & Ileocolonic & 4 & 22.2 & 14 & 77.8 & \\
\hline & & Colonic & 0 & 0.0 & 7 & 100.0 & \\
\hline \multirow[t]{3}{*}{ CD } & Disease & Non-stricturing, non-penetrating & 5 & 22.7 & 17 & 77.3 & 0.529 \\
\hline & behaviour & Stricturing & 4 & 36.4 & 7 & 63.6 & \\
\hline & & Peetrating & 2 & 16.7 & 10 & 83.3 & \\
\hline \multirow[t]{3}{*}{ CD } & Disease & Mild & 7 & 30.4 & 16 & 69.6 & 0.178 \\
\hline & Activity & Moderate & 1 & 7.1 & 13 & 92.9 & \\
\hline & (CDAI) & Severe & 3 & 37.5 & 5 & 62.5 & \\
\hline \multirow[t]{2}{*}{$\mathrm{CD}$} & Surgery & No & 7 & 23.3 & 23 & 76.7 & 0.709 \\
\hline & & Yes & 4 & 28.6 & 10 & 71.4 & \\
\hline \multirow[t]{2}{*}{ CD } & Anti-TNF & No & 8 & 25.0 & 24 & 75.0 & 0.607 \\
\hline & treatment & Yes & 3 & 23.1 & 10 & 76.9 & \\
\hline \multirow[t]{4}{*}{$\mathrm{CD}$} & Azathioprine & No & 6 & 37.5 & 10 & 62.5 & 0.130 \\
\hline & & Yes & 5 & 17.2 & 24 & 82.8 & \\
\hline & EGFR497 & & AA & AA & $\mathrm{GG}+\mathrm{AG}$ & $\mathrm{GG}+\mathrm{AG}$ & $\mathrm{p}$ \\
\hline & & & $\mathrm{N}$ & $\%$ & $\mathrm{~N}$ & $\%$ & \\
\hline \multirow[t]{3}{*}{ CD } & Localization & Ileal & 3 & 15.0 & 17 & 85.0 & 0.555 \\
\hline & & Ileocolon & 2 & 11.1 & 16 & 88.9 & \\
\hline & & Colon & 2 & 28.6 & 5 & 71.4 & \\
\hline \multirow[t]{3}{*}{ CD } & Disease & Non-stricturing, non-penetrating & 4 & 18.2 & 18 & 81.8 & 0.723 \\
\hline & Behavior & Stricturing & 2 & 18.2 & 9 & 81.8 & \\
\hline & & Penetrating & 1 & 8.3 & 11 & 91.7 & \\
\hline \multirow[t]{3}{*}{$\mathrm{CD}$} & Disease & Mild & 3 & 13.0 & 20 & 87.0 & 0.715 \\
\hline & Activity & Moderate & 2 & 14.3 & 12 & 85.7 & \\
\hline & & Severe & 2 & 25.0 & 6 & 75.0 & \\
\hline \multirow[t]{2}{*}{ CD } & Surgery & No & 4 & 13.3 & 26 & 86.7 & 0.392 \\
\hline & & Yes & 3 & 21.4 & 11 & 78.6 & \\
\hline \multirow[t]{2}{*}{$\mathrm{CD}$} & Anti- TNF & No & 5 & 15.6 & 27 & 84.4 & 0.680 \\
\hline & treatment & Yes & 2 & 15.4 & 11 & 84.6 & \\
\hline \multirow[t]{2}{*}{$\mathrm{CD}$} & Azathioprine & No & 3 & 18.8 & 13 & 81.2 & 0.484 \\
\hline & & Yes & 4 & 13.8 & 25 & 86.2 & \\
\hline
\end{tabular}

necrosis factor; CDAI, Crohn's disease activity index

Table 5: Evaluation of EGF +61 A/G and EGFR 497 polymorphisms in patients with UC in relation to disease type, localization, activity, treatment and operative status.

\begin{tabular}{llccccc} 
EGF61 & & \multicolumn{2}{c}{ GG } & \multicolumn{2}{c}{ GA+AA } & p \\
\hline & & $\mathrm{N}$ & $\%$ & $\mathrm{~N}$ & $\%$ & \\
\hline Localization & Proctitis & 4 & 28.6 & 10 & 71.4 & 0.224 \\
& Left-sided & 1 & 9.1 & 10 & 90.9 & \\
& Extensive & 8 & 38.1 & 13 & 61.9 & \\
Disease Activity (TW) & Mild & 6 & 27.3 & 16 & 72.7 & 0.975 \\
& Moderate & 6 & 28.6 & 15 & 71.4 & \\
& Severe & 1 & 33.3 & 2 & 66.7 & \\
Azathioprine treatment & No & 8 & 28.6 & 20 & 71.4 & 0.953 \\
& Yes & 5 & 27.8 & 13 & 72.2 & \\
\hline EGFR 497 & & AA & AA & GG+ & GG+ & p \\
& & & & AG & AG & \\
\hline \multirow{3}{*}{ Localization } & & $\mathrm{N}$ & $\%$ & $\mathrm{~N}$ & $\%$ & \\
& Proctitis & 0 & 0.0 & 14 & 100.0 & 0.554 \\
& Left-sided & 0 & 0.0 & 11 & 100.0 & \\
Disease Activity (TW) & Extensive & 1 & 4.8 & 20 & 95.2 & \\
& Mild & 0 & 0.0 & 22 & 100.0 & 0.544 \\
& Moderate & 1 & 4.8 & 20 & 95.2 & \\
& Severe & 0 & 0.0 & 3 & 100.0 & \\
Azathioprine treatment & No & 1 & 3.6 & 27 & 96.4 & 0.609 \\
& Yes & 0 & 0.0 & 18 & 100.0 & \\
\hline
\end{tabular}

UC: ulcerative colitis, EGF: epidermal growth factor, EGFR: epidermal growth factor receptor, TW: Truelove-Witts activity index

In this study, we investigated the presence of EGF +61 A/G and EGFR R497 polymorphisms in patients with IBD and the association of these polymorphisms with the clinical features of patients with CD and UC. In our study, the EGFR 497 AA genotype and A allele were significantly decreased in patients with UC compared with controls and patients with CD. However, there was no statistically significant difference between the three groups in EGF +61 genotype frequencies. Geng et al. [22] suggested as a result of their animal studies that EGF helped to recover damage resulting from intestinal ischemia and the reperfusion process. Even though IBD has unknown and unclear etiology to understand the disease, it has multifactorial mechanism including genetic, environmental and immunological mechanisms [23, 24]. In addition, Menard et al. [25] have worked with human fetal intestine culture and they have found the EGF regulates the genes which are related with inflammation process. Bedford et al. [26] have pointed out EGF therapy has the ability to increase the expression of interleukin 13 as an antiinflammatory cytokine. Therapeutic effects in experimental colitis models and the positive effects of necrotizing enterocolitis treatment have led to the use of EGF in the treatment of IBD.[27] EGF enema treatment was also found effective on the left colon and distal type UC[11]. The data coming from studies on the $\mathrm{EGF}+61 \mathrm{~A} / \mathrm{G}$ polymorphism in CRC showed that the $\mathrm{G}+$ allele and $\mathrm{G} / \mathrm{G}$ genotype were related with the presence of CRC and more advanced disease [11]. In addition, Shahbazi et al. [10] demonstrated that cells of individuals with the EGF +61 AA genotype produced less EGF compared with individuals who had EGF +61 AG and GG genotypes. Shahbazi et al. [10] also found that position on $\mathrm{EGF}+61, \mathrm{G}$ allele carriers express significantly more than A allele carriers.

In our study, the results indicate that the EGF +61 A allele is related with particularly active $C D$. In patients with $C D$ with $\mathrm{EGF}+61$ A alleles, there is a greater risk of increased disease activity index. The risk of using anti-TNF agents was also found to be increased. It was also found that patients with EGF +61AG polymorphism increased the risk of penetrating disease. In patients with UC, there was an increase in the risk of moderate and severe disease. This may be due to the low expression of EGF in patients with alleles of EGF $+61 \mathrm{~A}$ and consequent deterioration of the mucosal barrier and healing process. In this regard, there is a need for further studies.

EGFR plays an important role in the homeostasis of the colon epithelium, cell proliferation, barrier functions, and ion transport. In a recent study, it was found that microbial products such as lipopolysaccharide caused EGFR activation in macrophages, resulting in decreased anti-inflammatory cytokines such as interleukin (IL)-10 [28]. It has been found that colitis is exacerbated and healing is impaired. In addition to the present study, selective EGFR-depleted macrophages have been shown to increase IL-10 release resulting in the recovery of intestinal inflammation due to proinflammatory cytokine depletion [28].

EGFR R497K polymorphism leads to decreased intracellular signaling pathways by changing some processes such as cell growth factor and ligand binding, and decreased tyrosine kinase activation $[17,22,28]$. In our study, the EGFR497 AA genotype was significantly decreased in patients with UC compared with controls and patients with CD. The EGFR497 AA genotype has more attenuated functions than the GG polymorphism in terms of ligand binding, growth stimulation, and tyrosine kinase activation [28, 29].

In conclusion, this study was a preliminary study that EGF +61 and EGFR497 gene variants in patients with UC and CD. The EGFR 497 AA genotype was significantly decreased in patients with UC compared with controls and those with $\mathrm{CD}$. Further studies with larger sample groups are needed to clarify the role of the EGF +61 and EGFR 497 polymorphisms, and the development of the etiology and pathogenesis of IBD.

\section{Acknowledgements}

We would like to thank Mr. David F. Chapman for English editing. 


\section{References}

1. Mehta M, Ahmed S, Dryden G. Immunopathophysiology of inflammatory bowel disease: how genetics link barrier dysfunction and innate immunity to inflammation. Innate Immun. 2017;23:497-505.

2. Dieckgraefe BK, Korzenik JR, Anant S. Growth factors as treatment options for intestinal inflammation. Ann N Y Acad Sci. 2006;1072:3006.

3. Scott J, Patterson S, Rall L, Bell GI, Crawford R, Penschow J, Niall H, Coghlan J. The structure and biosynthesis of epidermal growth factor precursor. J Cell Sci. Suppl 1985;3:19-28.

4. Tang X, Liu H, Yang S. Li Z, Zhong J, Fang R. Epidermal Growth Factor and Intestinal Barrier Function. Mediators Inflamm. 2016;2016:1927348.

5. Kondo I, Shimizu N. Mapping of the human gene for epidermal growth factor receptor (EGFR) on the p13 leads to q22 region of chromosome 7. Cytogenet Cell Genet. 1983;35:9-14.

6. Yan F, Cao H, Cover TL, Washington MK, Shi Y, Liu L. Colon-specific delivery of a probiotic-derived soluble protein ameliorates intestinal inflammation in mice through an EGFR-dependent mechanism. J Clin Invest. 2011;121:2242-53.

7. Hormi K, Lehy T. Developmental expression of transforming growth factor-alpha and epidermal growth factor receptor proteins in the human pancreas and digestive tract. Cell Tissue Res. 1994;278:439-50.

8. Chaudhry A, Funa K, Oberg K. Expression of growth factor peptides and their receptors in neuroendocrine tumors of the digestive system. Acta Oncol. 1993;32:107-14.

9. Spindler KL, Nielsen JN, Ornskov D, Brandslund I, Jakobsen A. Epidermal growth factor (EGF) A61G polymorphism and EGF gene expression in normal colon tissue from patients with colorectal cancer. Acta Oncol. 2007;46:1113-7.

10. Shahbazi M, Pravica V, Nasreen N, Fakhoury H, Fryer AA, Strange RC, et al. Association between functionalpolymorphism in EGF gene and malignant melanoma. Lancet. 2002;359:397-401.

11. Wu GY, Hasenberg T, Magdeburg R, Bönninghoff R, Sturm JW, Keese M. Association between EGF, TGF-beta1, VEGF gene polymorphism and colorectal cancer. World J Surg. 2009;33:124-9.

12. Moriai T, Kobrin MS, Hope C, Speck L, Korc M. A variant epidermal growth factor receptor exhibits altered type alpha transforming growth factor binding and transmembrane signaling. Proc Natl Acad Sci USA. 1994;91:10217-21.

13. Hisamatsu $\mathrm{T}$, Inoue $\mathrm{N}$, Yajima $\mathrm{T}$, Izumiya $\mathrm{M}$, Ichikawa $\mathrm{H}$, Hibi $\mathrm{T}$. Psychological aspects of inflammatory bowel disease. J Gastroenterol. 2007;42:34-40.

14. Lurje G, Nagashima F, Zhang W. et al. Polymorphisms in cyclooxygenase-2 and epidermal growth factor receptor are associated with progression-free survival independent of K-ras in metastatic colorectal cancer patients treated with single-agent cetuximab. Clin Cancer Res. 2008;14:7884-95.

15. Ménard D, Tremblay E, Ferretti E, Yang D, Chang HM, Gordon MA, et al. Anti-inflammatory effects of epidermal growth factor on the immature human intestine. Physiol Genomics. 2012;44:268-80.

16. Miller SA, Dykes DD, Polesky HF. A simple salting out procedure for extracting DNA from human nucleated cells. Nucleic Acids Res. 1988;16:1215.

17. Zhang W, Park DJ, Lu B, Yang DY, Gordon M, Groshen S, et al. Epidermal growth factor receptor gene polymorphisms predict pelvic recurrence in patients with rectal cancer treated with chemoradiation. Clin Cancer Res. 2005;11:600-5.

18. Moriai T, Kobrin MS, Hope C,Speck L, Korc M. A variant epidermal growth factor receptor exhibits altered type alpha transforming growth factor binding and transmembrane signaling. Proc Natl Acad Sci USA. 1994;91:10217-21.

19. Van Assche G, Dignass A, Panes J, Beaugerie L, Karagiannis J, Allez $\mathrm{M}$, et al. The second European evidence-based consensus on the diagnosis and management of Crohn's disease: definitions and diagnosis. J Crohns Colitis. 2010;4:7-27
20. Dichi I, Burini RC. [Inflammatory bowel disease activity index: clinical and laboratory indicators]. Arq Gastroenterol. 1995;32:121-30.

21. Satsangi J, Silverberg MS, Vermeire S, Colombel JF. The Montreal classification of inflammatory bowel disease: controversies, consensus, and implications. Gut. 2006;55:749-53.

22. Geng Y, Li J, Wang F, Li Q, Wang X, Sun L, Li W. Epidermal growth factor promotes proliferation and improves restoration after intestinal ischemia-reperfusion injury in rats. Inflammation. 2013;36:670-9.

23. Burrin DG, Petersen Y, Stoll B, Sangild P. Glucagon-like peptide 2: a nutrient-responsive gut growth factor. J Nutr. 2001;131:709-12.

24. Housley RM, Morris CF, Boyle W, Ring B, Biltz R, Tarpley JE, et al. Keratinocyte growth factor induces proliferation of hepatocytes and epithelial cells throughout the rat gastrointestinal tract. J Clin Invest. 1994;94:1764-77.

25. Ménard D, Tremblay E, Ferretti E, Babakissa C, Perron N, Seidman EG, et al. Anti-inflammatory effects of epidermal growth factor on the immature human intestine. Physiol Genomics. 2012;44:268-80.

26. Bedford A, Chen T, Huynh E, Zhu C, Medeiros S, Wey D, et al. Epidermal growth factor containing culture supernatant enhances intestine development of early-weaned pigs in vivo: potential mechanisms involved. J Biotechnol. 2015;196-197:9-19.

27. Clark JA, Doelle SM, Halpern MD, Saunders TA, Holubec H, Dvorak K, et al. Intestinal barrier failure during experimental necrotizing enterocolitis: protective effect of EGF treatment. Am J Physiol Gastrointest Liver Physiol. 2006;291:G938-49.

28. Lu N, Wang L, Cao H, Liu L, Van Kaer L, Washington MK, et al. Activation of the epidermal growth factor receptor in macrophages regulates cytokine production and experimental colitis. J Immunol 2014;192:1013-23.

29. Sinha A, Nightingale J, West KP, Berlanga-Acosta J, Playford RJ. Epidermal growth factor enemas with oral mesalamine for mild-tomoderate left-sided ulcerative colitis or proctitis. N Engl J Med 2003;349:350-7. 